\title{
Investigations on the effectiveness of Levamisol as a medication against the eel parasite Anguillicola crassus (Nematoda)
}

\author{
F. Hartmann \\ Institut für Hydrobiologie und Fischereiwissenschaft der Universität Hamburg, Olbersweg 24, D-2000 Hamburg 50, \\ Federal Republic of Germany
}

\begin{abstract}
Two different dosages, 2 and $5 \mathrm{mg} \mathrm{l}^{-1}$, of Levamisol (anthelmintic), applied in a water bath, were tested over a long term against various developmental stages of the swim bladder parasite Anguillicola crassus in the European eel Anguilla anguilla. Almost all preadult and adult nematodes, which live in the Iumen of the swim bladder, show signs of paralysis $6 \mathrm{~h}$ after therapy. During the following weeks, many are killed off. However, some nematodes are able to regenerate after suffering sublethal damage. The mortality rates of preadult and adult parasites were similar at both dosages. The tinal juvenile stages of the parasite, which live in the swim bladder wall, are less sensitive to the medication. The highest mortality rate observed among this group was $48 \%$. It was mainly the larger juveriles, from 3 to $5 \mathrm{~mm}$, that suffered lethal damage. especially at the higher dosage. About $3 w k$ after treatment, the infestation rate with intact nematodes in the swim bladder lumen begins to increase again, due to the recovery of preadult and adult nematodes and the migration of surviving juveniles into the lumen of the swim bladder. The eggs and newly hatched larvae $\left(L_{2}\right)$ of $A$. crassus, which are released in the lumen of the swim bladder, show no reaction to the medicine.
\end{abstract}

\section{INTRODUCTION}

At the beginning of the 1980s, swim bladder nematodes of the genus Anguillicola, were discovered for the first time in Europe (Paggi et al. 1982, Neumann 1985). Since then, these parasites have spread throughout many parts of Europe, and the infestation rate in several water bodies has come to exceed $90 \%$ (Peters \& Hartmann 1986, Decker \& Willigen 1987, Taraschewski et al. 1987. Wondrak 1988, Koops \& Hartmann 1989). The parasites are supposed to have arrived with live eels transported from the Far East or New Zealand (Koops 1986). At least 2 species of this genus, Anguillicola crassus (Kuwahara et al. 1974) from Japan and A. novaezelandiae (Moravec \& Taraschewski 1988) from New Zealand seem to be contributing to the epizootic

The adult and preadult parasites live in the lumen of the swim bladder and feed on the blood of the host (Kuwahara et al. 1974). Eggs and hatching secondstage larvae $\left(\mathrm{L}_{2}\right)$ were released by mature female nematodes in the swim bladder lumen. From there, they leave the host through the ductus pneumaticus and the digestive tract into the water, where freshwater cyclopoid copepods are known to act as intermediate hosts (Hirose et al. 1976, De Charleroy et al. 1987) and where there may be other hosts, as well (Koops \& Hartmann 1987, De Charleroy et al. 1987). After invading the eel, the final juvenile stages of Anguillicola crassus first establish themselves in the tissue of the swim bladder wall.

A large number of parasites in the swim bladder is harmful to the heaith of the host (Yamaguti 1935, Egusa 1979, Neumann 1985, Hartmann 1987, Canestri-Trotti 1987). The eel culture industry, especially, is interested in finding an effective medication for treating this disease. Taraschewski et al. (1988) tested the effectiveness of 5 anthelmintics against the adult and preadult parasites and investigated various methods of application. They found that Levamisol was the most effective of these and that it can bring about the complete recovery of eel.

In the present investigation, the long-term effects of various dosages of Levamisol on the individual developmental stages of the parasite were investigated. The effectiveness of this medicine was tested under conditions that prevail in commercial eel culture facilities. 
Experiments were conducted using Concurat-L $10 \%$ (Bayer), a commercial preparation containing Levamisol. Concurat- $L$ is a powder that is easily dissolved in water. It consists of $10 \%$ Levamisol and $90 \%$ lactose. It is a broad-spectrum anthelmintic used in animal husbandry that is generally mixed with the feed. Levamisol is the $\mathrm{L}(-)$ isomer of Tetramisol (Imidazothiazole), and in various nematode species it causes a spastic paralysis, thought to result from a blocking of the neuromuscular synapses (Raether 1988). The exact biochemical activity is still unknown.

\section{MATERIALS AND METHODS}

Naturally infested stocking eels from the lower Elbe River, FRG, were available for the investigations. Their average length was $33.7 \mathrm{~cm}(23.0$ to $42.3 \mathrm{~cm})$, and they weighed $51.2 \mathrm{~g}(10.5$ to $130.9 \mathrm{~g})$, on average. Before the start of experiments, 39 control eels were killed to determine the actual infestation rate. For therapy experiments, two $1800 \mathrm{l}$ aquaria were each stocked with eels weighing a total of $100 \mathrm{~kg}$. After a $24 \mathrm{~h}$ adaptation period and 1 change of water, anthelmintic was added. Two concentrations, 2 and $5 \mathrm{mg} \mathrm{I}^{-1}$, of Levamisol were applied in a freshwater bath. These concentrations were chosen after reference to the work of Taraschewski et al. (1988), who used $1 \mathrm{mg} \mathrm{I}^{-1}$ of Levamisol for eels kept at a lower stocking density. According to Taraschewski et al. (1988), the LD $_{50}$ of Levamisol for eels is about $250 \mathrm{mg} \mathrm{l}^{-1}$.

The aquaria were well aerated and kept at a water temperature of 15.5 to $16.5^{\circ} \mathrm{C}$ and water hardness of $15^{\circ} \mathrm{dH}$. After $24 \mathrm{~h}$ therapy, ca 200 eels were removed from each aquarium and placed in smaller (250 l), round basins. In these, they were kept for $9 \mathrm{wk}$ under the same experimental conditions without medication or food at temperatures from 19 to $21^{\circ} \mathrm{C}$.

The investigations began $6 \mathrm{~h}$ after the termination of therapy. From each experimental group, 5 to 12 eels were killed weekly for examination over a period of 2 mo. Eels were narcotized and killed with a $0.1 \%$ solution of Benzocain (ethyl 4-aminobenzoate). According to our findings, Benzocain does not affect the swim bladder nematodes

Examination of the adult and preadult parasites from the swim bladder lumen. The swim bladder was removed and opened. The number of parasites and the length of each were determined. Worms $\leq 1.25 \mathrm{~cm}$ were designated preadults, and their gonads are still in a very early stage of development. In those parasites $>1.25 \mathrm{~cm}$, designated adults, gonads were plainly evident

The vitality of each parasite was evaluated and categorized as follows: (1) intact worms showing nor- mal activity, which is a slow to lively wriggling movement; (2) damaged (paralyzed) worms that remain motionless in the opened swim bladder and first show a reaction by very slowly bending after receiving the mechanical stimulus of being pinched with a forceps; (3) dead worms do not react to mechanical stimuli. They are generally limp, remain in an extended position, and have swellings and thickenings of the body, especially near the head

Examination of the final juvenile stages of Anguillicola crassus from the swim bladder wall. Tissue of the swim bladder was examined at a magnification of $160 \times$ under a stereo microscope. A search was made for juvenile worms by extending the tissue bit by bit over a light source. In addition, a total of 34 eels were selected at random at various times duriny lie 3 id to 9th wk, and the tissue parasites they contained sorted into 2 size classes, $<3.0$ and $\geq 3.0 \mathrm{~mm}$.

Judging the health of the juvenile stages was difficuit because they remain embedded in the tissue. Only 2 classes were recognized: (1) intact juveniles, which were recognized by their slow wriggling movements in the tissue and searching movements of the head; (2) dead juveniles, which are relatively opaque and limp and show advanced stages of lysis.

Examination of the eggs and newly hatched larvae $\left(\mathrm{L}_{2}\right)$ from the swim bladder lumen. Eggs and $\mathrm{L}_{2}$ were usually present in large numbers. Therefore, only their presence or absence could be determined. Using $400 \times$ magnification, their health condition could be evaluated as follows: (1) intact larvae, showing rapid movements both in the egg shell and after hatching; (2) dead larvae, which do not move. These sometimes exist only as remains of the integument.

\section{RESULTS}

\section{Adult and preadult nematodes in the swim bladder lumen}

In the control group, $90 \%$ of eels contained adult and preadult parasites identified as Anguillicola crassus. The mean rate of infestation was 8.0 nematodes per swim bladder; the maximum number present in a swim bladder was 66 . The parasites were all intact.

Six hours after termination of medication, the parasites in swim bladders of eels that received anthelmintic, almost all showed symptoms of severe paralysis which sometimes led to death.

The average number of intact nematodes in each eel decreased to 0.2 after medication with $2 \mathrm{mg}^{-1}$ Levamisol and to 0 after the addition of $5 \mathrm{mg} \mathrm{l}^{-1}$ (Fig. 1). At first, this situation remained unchanged, but after the $3 \mathrm{rd}$ wk in aquaria to which $2 \mathrm{mg} \mathrm{l}^{-1}$ had been 


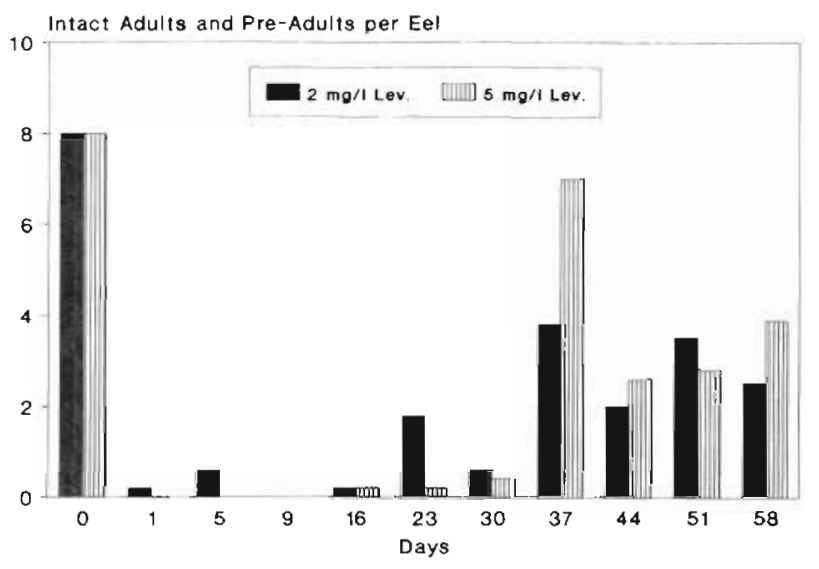

Fig. 1. Anguillicola crassus. Average intensities of infestation by intact adult and pre-adult nematodes in eels receiving 2 or $5 \mathrm{mg} \mathrm{t}^{-1}$ Levamisol during the experimental period

added, and after the 5 th wk where the dosage was 5 $\mathrm{mg} 1^{-1}$, a significant increase in the number of healthy nematodes was detected. By the 9 th wk after the addition of the lower dosage, the average infestation intensity had increased to 2.5 worms per eel. The corresponding average for the group that received the higher dosage was even greater at 3.9 nematodes per eel.

The percentage of intact, damaged, and dead preadult and adult nematodes during the course of the experiments are shown in Fig. 2. The percentage of intact parasites began to increase rapidly in the $3 \mathrm{rd} \mathrm{wk}$ after the $2 \mathrm{mg} \mathrm{l}^{-1}$ Levamisol therapy and in the 4 th wk after the $5 \mathrm{mg} \mathrm{l}^{-1}$ therapy By the 7 th $w \mathrm{k}$, the rate had reached $90 \%$ among the group that had received the lower dosage and $95 \%$ among those treated with the higher one. Immediately after therapy, the percentage of damaged, motionless preadult and adult nematodes was very high. It was $88 \%$ after the low dosage and $90 \%$ after the high dose of Levamisol. Thereafter, it decreased continuously, and by about the 7 th wk, the value lay between 0 and $10 \%$ of the total parasite population in both Levamisol dosages. The number of dead nematodes in the swim bladder increased to between 60 and $70 \%$ by the 5 th wk, then decreased again to about $5 \%$ after the 7 wk. All length classes of the preadult and adult parasites were found to have similar death rates.

Dead preadult and adult nematodes were often found in the ductus pneumaticus of eels and in the aquaria water These specimens were usually considerably decomposed. Occasionally, dead preadult and adult worms in fairly good conditions were found at the bottom of the aquaria.

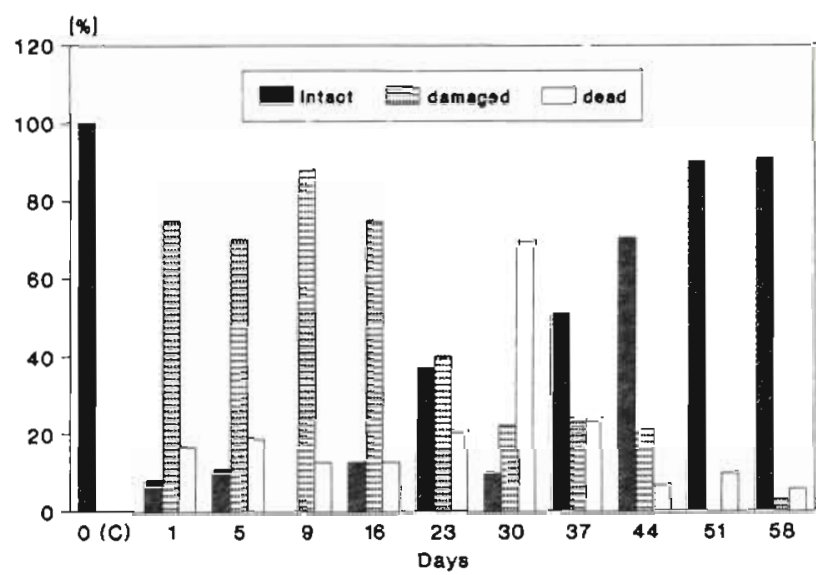

b

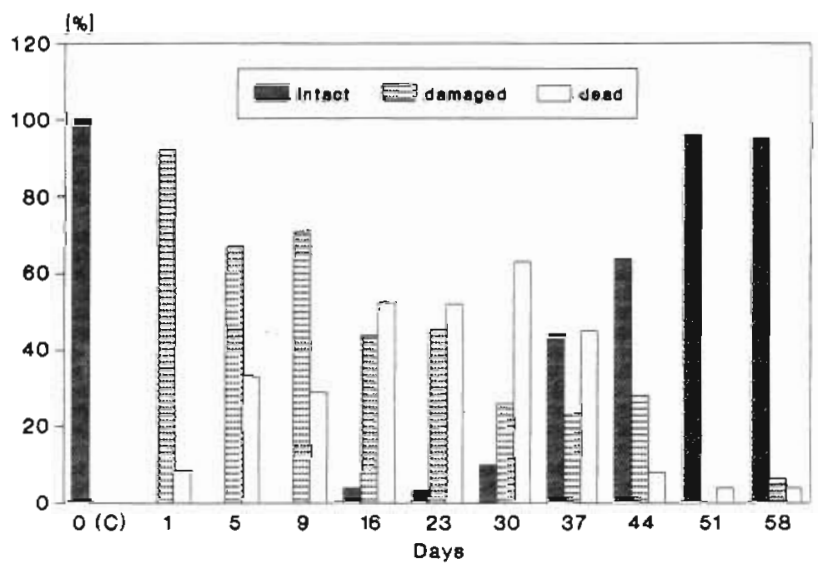

Fig. 2. Anguillicola crassus. The percent distribution of intact, damaged, and dead preadult and adult nematodes in control eels (C) and eels treated with $2 \mathrm{mg} \mathrm{l}^{-1}$ (a) and $5 \mathrm{mg} \mathrm{l}^{-1}$ (b) Levamisol

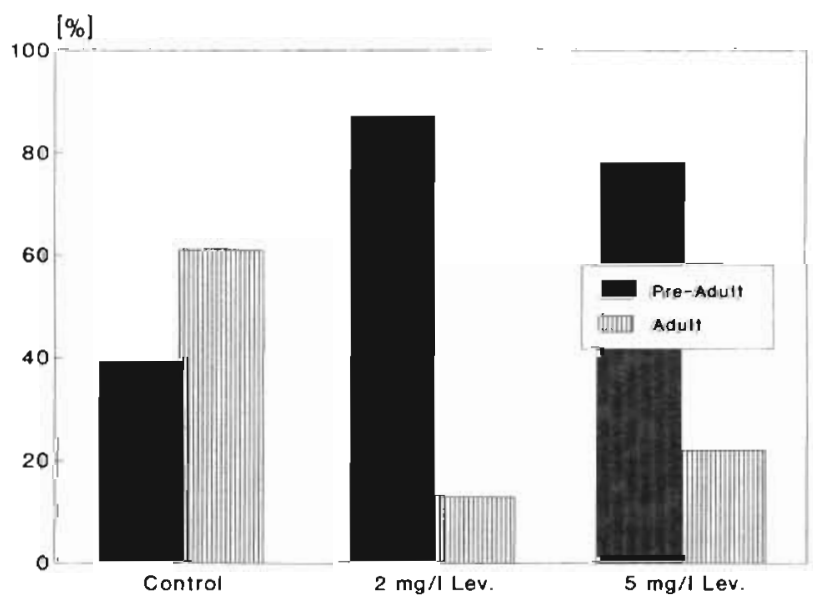

Fig. 3. Anguillicola crassus. Percent distribution of preadult and adult nematodes in the swim bladder lumina of control and experimental eels during the 7 th through 9 th wk of the experiment 
The percentage of preadult nematodes in the control eels was $40 \%$ of the total population of intact parasites in the swimbladder lumina. After therapy, this percentage at first fluctuated greatly, and thereafter, it increased to about double the initial value during the last 3 wk of the investigation. At this time, $87 \%$ of the worms in the group treated with $2 \mathrm{mg} \mathrm{l}^{-1}$ Levamisol and $78 \%$ of those treated with $5 \mathrm{mg} \mathrm{l}^{-1}$ were preadults. The number of adult worms decreased correspondingly (Fig. 3).

\section{Juvenile stages in the swim bladder wall}

The final juvenile stages of Anguillicola crassus $\left(\mathrm{L}_{3}\right.$ and $\mathrm{L}_{4}$ ) inhabit the tissue of the swim bladder wall for several weeks and probably feed on cells. When the juveniles reach a length of about $5 \mathrm{~mm}$, they penetrate the swim bladder lumen.

An average of 7 such tissue parasites were found in each swim bladder. The maximum number present was 122. The ratio of large $(\geq 3.0 \mathrm{~mm})$ to small $(<3.0 \mathrm{~mm})$ juveniles was 1:1.85. All juveniles in control eels were intact.

Juveniles of Anguillicola crassus react to anthelmintic to very different degrees: Table 1 shows that the higher dosage had a more rapid and stronger effect. However, many of the parasites survived, regardless of which dosage was used. The highest mortality rates were $48 \%$ during the 6 th $w \mathrm{k}$ after the application of $2 \mathrm{mg} \mathrm{l}^{-1}$ Levamisol and $41 \%$ during the 5 th $w \mathrm{k}$ after the application of $5 \mathrm{mg}^{-1}$ Levamisol.

Lethal damage was more frequently observed among larger juveniles in the swim bladder wall than among the smaller ones (Table 2). The mortality rate of the worms $<3.0 \mathrm{~mm}$ was about $2.5 \%$ after the application of the medication at both concentrations. Among the larger juvenile stages, the mortality rate was significantly lower at the lower dosage: $17.2 \%$ after the application of $2 \mathrm{mg} \mathrm{l}^{-1}$ and $28.5 \%$ after the application of the $5 \mathrm{mg} \mathrm{I}^{-1}$ Levamisol.

\section{Eggs and newly hatched larvae $\left(L_{2}\right)$ in the lumen of the swim bladder}

About half of the control eels contained eggs and $L_{2}$, 0.26 to $0.33 \mathrm{~mm}$ in length, in the lumina of their swim bladders. Even after therapy, eggs and living $\mathrm{L}_{2}$ were frequently found in eels until the 8 th wh of the experiment (Table 3 ). In no cases were $L_{2}$ found that were dead or showed signs of decreased vitality. During the 9th wk, only 1 eel examined was found to contain a few larvae, and these were all deact.
Table 1. Anguillicola crassus. Effect of Levamisol (Lev.) on juveniles inhabiting the swim bladder wall

\begin{tabular}{|c|c|c|c|c|}
\hline Dose & Day & $\begin{array}{l}\text { No. } \\
\text { eels }\end{array}$ & $\begin{array}{l}\text { Total no. } \\
\text { parasites }\end{array}$ & $\begin{array}{l}\% \text { Dead } \\
\text { parasites }\end{array}$ \\
\hline Controls & 0 & 39 & 311 & 0 \\
\hline $2 \mathrm{mg}$ Lev. $\mathrm{I}^{-1}$ & $\begin{array}{r}1 \\
5 \\
9 \\
16 \\
23 \\
30 \\
37 \\
44 \\
51 \\
58\end{array}$ & $\begin{array}{r}15 \\
5 \\
5 \\
5 \\
6 \\
5 \\
5 \\
5 \\
10 \\
12\end{array}$ & $\begin{array}{r}25 \\
23 \\
23 \\
50 \\
104 \\
16 \\
42 \\
143 \\
75 \\
68\end{array}$ & $\begin{array}{r}0 \\
0 \\
4 \\
20 \\
8 \\
0 \\
48 \\
3 \\
5 \\
8\end{array}$ \\
\hline $5 \mathrm{mg} \mathrm{Lev.} \mathrm{l}^{-1}$ & $\begin{array}{r}1 \\
5 \\
9 \\
16 \\
23 \\
30 \\
37 \\
44 \\
51 \\
58\end{array}$ & $\begin{array}{r}15 \\
5 \\
5 \\
5 \\
6 \\
5 \\
5 \\
9 \\
10 \\
12\end{array}$ & $\begin{array}{r}59 \\
22 \\
70 \\
2 \\
32 \\
37 \\
203 \\
93 \\
32 \\
103\end{array}$ & $\begin{array}{r}2 \\
23 \\
2 \\
0 \\
0 \\
41 \\
19 \\
13 \\
19 \\
14\end{array}$ \\
\hline
\end{tabular}

Table 2. Anguillicola crassus. Mortality rates of 2 size classes of juventles in the swim bladder wall during the 3rd to 9 th wk after treatment with Levamisol

\begin{tabular}{|c|c|c|c|c|c|}
\hline \multirow[t]{2}{*}{ Dose } & \multirow[t]{2}{*}{$\begin{array}{l}\text { No. } \\
\text { eels }\end{array}$} & \multicolumn{2}{|c|}{$\begin{array}{l}\text { Juveniles } \\
<0.3 \mathrm{~mm}\end{array}$} & \multicolumn{2}{|c|}{$\begin{array}{l}\text { Juveniles } \\
\geq 3.0 \mathrm{~mm}\end{array}$} \\
\hline & & $\begin{array}{l}\text { Intact } \\
\text { (Total) }\end{array}$ & $\begin{array}{c}\text { Dead } \\
(\%)\end{array}$ & $\begin{array}{l}\text { Intact } \\
\text { (Total) }\end{array}$ & $\begin{array}{c}\text { Dead } \\
(\%)\end{array}$ \\
\hline $2 \mathrm{mg}$ Lev. $\mathrm{I}^{-1}$ & 15 & 195 & 2.5 & 82 & 17.2 \\
\hline $5 \mathrm{mg} \mathrm{Lev} \mathrm{l}^{-1}$ & 19 & 281 & 2.4 & 118 & 28.5 \\
\hline
\end{tabular}

\section{DISCUSSION}

The investigations revealed that the effect of Levamisol is different for the developmental stages of Anguillicola crassus: the adults and preadults, the final juvenile stages $\left(\mathrm{L}_{3}, \mathrm{~L}_{4}\right)$, and nuwly hatched larvae $\left(\mathrm{L}_{2}\right)$.

Preadults and adults, in the swim bladder lumen of the host, show considerable loss of vitality for a $3 \mathrm{wk}$ period after therapy. Some nematodes suffer damage and subsequently die. The greatest number of dead nematodes are found $30 \mathrm{~d}$ after application of Levamisol. Then, there is a decrease in the number of dead nematodes in the swim bladders, while nematode remains are found in the aquaria. It must be assumed that these remains were ejected from eels. This is not surprising since during the normal life cycle, eggs and 
Table 3. Anguillicola crassus. Occurrence of parasite eggs and newly hatched larvae in swim bladders of eels examined during experimental period. ${ }^{\cdot}=$ dead larvae

\begin{tabular}{|c|c|c|c|c|}
\hline Dose & Day & $\begin{array}{l}\text { No. } \\
\text { eels }\end{array}$ & $\begin{array}{l}\text { Eels containing } \\
\text { eggs and larvae }\end{array}$ & $\%$ \\
\hline Controls & 0 & 39 & 22 & 56 \\
\hline $2 \mathrm{mg}$ Lev. $\mathrm{I}^{-1}$ & $\begin{array}{r}1 \\
5 \\
9 \\
16 \\
23 \\
30 \\
37 \\
44 \\
51 \\
58\end{array}$ & $\begin{array}{r}15 \\
5 \\
5 \\
5 \\
6 \\
5 \\
5 \\
5 \\
10 \\
14\end{array}$ & $\begin{array}{l}6 \\
2 \\
3 \\
1 \\
2 \\
2 \\
4 \\
1 \\
2 \\
1\end{array}$ & $\begin{array}{r}40 \\
40 \\
60 \\
20 \\
33 \\
40 \\
80 \\
20 \\
20 \\
0\end{array}$ \\
\hline $5 \mathrm{mg}$ Lev. $1^{-1}$ & $\begin{array}{r}1 \\
5 \\
9 \\
16 \\
23 \\
30 \\
37 \\
44 \\
51 \\
58\end{array}$ & $\begin{array}{r}15 \\
5 \\
5 \\
5 \\
6 \\
5 \\
5 \\
9 \\
10 \\
10\end{array}$ & $\begin{array}{l}7 \\
4 \\
4 \\
2 \\
2 \\
1 \\
3 \\
2 \\
4 \\
0\end{array}$ & $\begin{array}{r}47 \\
80 \\
80 \\
40 \\
33 \\
20 \\
60 \\
22 \\
40 \\
0\end{array}$ \\
\hline
\end{tabular}

larvae of the swim bladder parasites also find their way to the outside through the ductus pneumaticus and the digestive tract together with faecal material. This pathway can just as well serve to conduct motionless material, such as dead nematodes, to the outside. The living parasites may actively avoid such an expulsion through their wriggling movements.

The occurrence in the aquaria of several dead nematodes in good condition suggests that these had passed through the esophagus and were released through the mouth.

It is clearly evident that 5 or $6 \mathrm{wk}$ after therapy, the number of intact nematodes in the lumen of the swim. bladder begins to continually increase and the number of damaged or motionless parasites decreases. This was true regardless of which dosage was used. The harmful effects of anthelmintic on the parasites inhabiting the swim bladder lumen are therefore temporally limited.

Because the mortality rates of the nematodes inhabiting the swim bladders are similar for all length groups of the parasite, the preadults that begin to appear in increasing numbers during the 3rd wk after therapy must be recruited largely from juveniles that penetrate the lumen from the swim bladder wall.

The effectiveness of Levamisol concentrations tested on the final juvenile stages of Anguillicola crassus in the swim bladder wall seems to be considerably less than that observed against the preadults and adults in the lumen of that organ. This finding may be explained by a lower sensitivity of that stages to Levamisol. Another explanation could be that the residence in the swim bladder tissue or the form of nutrition makes it difficult for the anthelmintic to reach the juveniles. Their mortality rate is below $50 \%$. The larger juveniles in the tissue of the wall are more sensitive to the medication than the smaller ones.

Levamisol is apparently very ineffective against eggs and newly hatched larvae $\left(\mathrm{L}_{2}\right)$ in the swim bladder lumen of eel. After the 8th wk, however, no more intact eggs or larvae could be found. Apparently, eggs and larvae that were produced prior to therapy are gradually released into the water. This process seems to be completed after about $8 \mathrm{wk}$. At this time, the maximum life span of the larvae still in the swim bladder seems to be reached, and those that have failed to leave that organ die off. After the newly immigrated juveniles have matured and the preadults and adults with sublethal damages have recovered, a renewed production of eggs and larvae is to be expected.

A single treatment with Levamisol seems to have little effectiveness. This contradicts the findings of Taraschewski et al. (1988). The $5 \mathrm{mg} \mathrm{I}^{-1}$ concentration of Levamisol works faster in some cases and effects a higher short-term mortality among Anguillicola crassus than the lower dosage of $2 \mathrm{mg} \mathrm{l}^{-1}$. However, after the 9 wk observation period, it was found to be no more effective in curing the eels.

Possibly, it will be necessary to treat the eels several times at the dosages used. The second treatment should be scheduled more than $4 \mathrm{wk}$ after the first since at this time, the first signs of regeneration by the adult and preadult nematodes can be expected. Subsequent treatments should be scheduled at greater intervals to kill off the juveniles that gradually penetrate into the swim bladder lumen.

The treated eels continue to release parasite larvae, which can produce new infestations if the intermediate hosts, cyclopoid copepods, are present. Additional to the therapy in eel culture facilities an elimination of these small crustaceans should also be considered to break the life cycle of the parasites. In this way, the introduction of new parasites into the culture facilities by the copepods can also be prevented.

These measures along with multiple treatments with Levamisol are suitable for eel culture facilities that hold eels for long periods of time. A similar treatment of eels in natural water bodies is not possible.

Acknowledgements. Special thanks are due to Dr Gabriele Peters for numerous valuable discussions during the review of the manuscript. The work was carried out with the financial support of the Federal Ministry for Nutrition, Agriculture, and 
Forests. The paper is based on doctoral research performed at the Faculty of Biology, University of Hamburg. The therapy on the eels was carried out at the Eel Shipping Station of the German Fishery Society through the cooperation of Mr Rosengarten. The Bayer Corporation supplied the anthelmintic.

\section{LITERATURE CITED}

Canestri-Trotti, G. (1987). Occurrence of the nematode Anguillicola crassa Kuwahara, Niimi \& Itagaki, 1974 in eels from the Po delta, Italy. Bull. Eur Ass. Fish Pathol. 7 (5): 109-111

De Charleroy, D., Thomas, K., Belpaire, C. (1987). Problems concerning the species determination, biology and diagnostical methods of Anguillicola, a swim-bladder nematode in the european eel (Anguilla anguilla L.). EIFAC (FAO). Working party on eel. Bristol, UK, 13-16 April 1987

Decker, W. Willigen, J.van (1987). Short note on the distribution and abundance of Anguilicoid in ike Netherlands. EIFAC (FAO). Working party on eel. Bristol, UK, 13-16 April

Egusa, S. (1979). Notes on the culture of the European eel (Anguilla anguilla L.) in Japanese eel farming ponds. Rapp. P.-v. Réun. Cons perm. int. Explor. Mer. 174: 51-58

Hartmann, S. (1987). Schwimmblasenwürmer beim Aal. Fisch. Teichwirt $38(1): 2-3$

Hirose, H., Sekino, T., Eguza, S. (1976). Notes on the egg deposition, larval migration and intermediate host on the nematode Anguillicola crassa parasitic in the swim bladder of eels. Fish Pathology 11:27-31

Koops, H. (1986). Untersuchungen zum Befall von Farmaalen mit Anguillicola. Inf. Fischw. 33 (4): 175-177

Koops, H., Hartmann, F. (1987). Infection of eels from different regions with Anguillicola. EIFAC (FAO). Working party on eel. Bristol, UK, 13-16 April 1987

Koops, H., Hartmann, F. (1989). Anguillicola-infestations in Germany and in German eel imports. J. appl. Ichthyol. 1: $41-45$

Responsible Subject Editor-Professor W. Körting, Hannover, F.R. Germany
Kuwahara, A., Niimi, A., Itagaki, H. (1974). Studies on a nematode parasitic in the air bladder of the eel. I. Description of Anguillicola crassa n. sp. (Philometridea, Anguillicolidae). Jap. J. Parasit. 23: 275-279

Moravec, F. Taraschewski, H. (1988). Revision of the genus Anguillicola Yamaguti, 1935 (Nematoda: Anguillicolidae) of the swimbladder of eels, including descriptions of two new species, $A$. novaezelandiae sp.n. and $A$. papernai sp. n. Folia Parasitol. (Prague) 35: 125-146

Neumann, W. (1985). Schwimmblasenparasit Anguillicola bei Aalen. Fisch. Teichwirt. 36 (11): 322

Paggi, L., Orecchia, P., Minervini, R., Matiucci, S. (1982). Sulla comparsa di Anguillicola australiensis JOHNSTON et MAWSON 1940 in Anguilla anguilla del Lago di Bracciano. Parasitologia, Leningrad 24: 139-144

Peters, G., Hartmann, F. (1986). Anguillicola, a parasitic nematode of the swim bladder spreading among eel populations in Europe. Dis. aquat. Org. 1.229-230

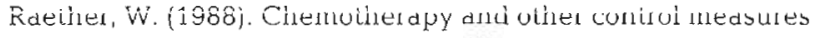
of parasitic diseases in domestic animals and man. In: Mehlhorn, H. (ed.) Parasitology in focus. Springer-Verlag, Berlin, Heidelberg, New York, p. 739-852

Taraschewski, H., Moravec, F., Lamah, T., Andres, K. (1987) Distribution and morphologie of two helminths recently introduced into European eel populations: Anguillicola crassus (Nematoda, Dracunculoidea) and Paratenuisentis ambiguus (Acanthocephala, Tenuisentidae). Dis. aquat. Org. 3: $167-176$

Taraschewski, H., Renner, C., Mehlhorn, H. (1988). Treatment of fish parasites. 3. Effects of levamisole- $\mathrm{HCl}$, metrifonate, febendazole, mebendazole, and ivermectin on Anguillicola crassus (nematodes) pathogenic in the air bladder of eels. Parasitol. res. 74: 281-289

Wondrak, P. (1988). Schwimmblasenwürmer beim Aal bereits in Bayern. Fisch. Teichwirt 39 (7): 207-208

Yamaguti, S. (1935). Studies on the helminth fauna of Japan. Pt. 9. Nematodes of fishes I. Jap. J. Zool. 6: 337-386

Manuscript first received: February 2, 1989

Revised version accepted: August 15, 1989 